\title{
Hepatitis B Surface Antigen Decline during Sofosbuvir and Ribavirin Therapy in Hepatitis B Inactive Carriers Who Were Co-infected with Hepatitis C
}

\author{
Shunsuke Sato, Hironori Tsuzura, Yuji Kita, Yuji Ikeda, Daishi Kabemura, Sho Sato, \\ Nozomi Amano, Noboru Yatagai, Ayato Murata, Yuji Shimada and Takuya Genda
}

\begin{abstract}
:
Direct-acting antiviral (DAA) therapy carries a potential risk of inducing hepatitis B virus (HBV) reactivation. However, the HBV kinetics during and after DAA therapy in patients co-infected with hepatitis $\mathrm{C}$ virus (HCV) and HBV remain unknown. We retrospectively evaluated the HBV kinetics during and after sofosbuvir/ribavirin therapy in four HBV inactive carriers co-infected with $\mathrm{HCV}$. HCV was eradicated in all patients. Changes in HBV-DNA levels during treatment differed among patients. The hepatitis B surface antigen (HBsAg) levels uniformly decreased (mean $-0.530 \log \mathrm{IU} / \mathrm{mL}$ ) by the end of treatment and returned to near the baseline in all patients. Sofosbuvir/ribavirin therapy thus demonstrated a suppressive effect on HBsAg.
\end{abstract}

Key words: hepatitis B virus, hepatitis C virus, sofosbuvir, ribavirin, hepatitis B surface antigen

(Intern Med 60: 3569-3572, 2021)

(DOI: 10.2169/internalmedicine.7337-21)

\section{Introduction}

Hepatitis C virus (HCV) infection is an important public health problem leading to liver cirrhosis and hepatocellular carcinoma. Recent advances in direct-acting antivirals (DAAs) for HCV have dramatically improved the sustained virologic response (SVR) rate.

Hepatitis B virus (HBV) infection is another major cause of chronic liver disease, and co-infections with $\mathrm{HBV}$ and $\mathrm{HCV}$ are not rare in HBV endemic areas. HBV co-infection does not substantially influence the efficacy of current DAA therapy. However, there is a risk of HBV reactivation following DAA-induced HCV eradication. Current HCV treatment guidelines from the United States, the European Union, and Japan recommend that all patients who initiate DAA therapy be assessed for HBV co-infection by hepatitis B surface antigen (HBsAg) and for previous HBV infection by hepatitis B surface antibody and core antigen (1-3). However, the detailed HBV kinetics during and after DAA therapy in patients co-infected with $\mathrm{HCV}$ and $\mathrm{HBV}$ remain unknown.
Therefore, we retrospectively examined the HBV kinetics during and after DAA therapy with sofosbuvir and ribavirin in four $\mathrm{HBV}$ inactive carriers co-infected with $\mathrm{HCV}$.

\section{Case Reports}

All four patients received sofosbuvir (400 mg) once daily and ribavirin (weight-based dose) twice daily for 12 weeks. All patients had no history of interferon therapy and showed negative findings on a human immunodeficiency virus antibody test before starting DAA therapy.

The HBV status was assessed in all patients by the plasma levels of HBV-deoxyribonucleic acid (DNA), HBV genotype, serum HBsAg, anti-hepatitis B surface antibody (anti-HBs), and hepatitis B envelope antigen ( $\mathrm{HBeAg}$ ) before DAA therapy (Table). Serum HBsAg levels were quantified using the Abbott Architect HBsAg QT assay [Abbott Japan, Tokyo, Japan; lower limit of quantification (LLQ), $0.05 \mathrm{IU} / \mathrm{mL}]$. Plasma HBV-DNA was quantified using the COBAS 6800/8800 system (Roche Diagnostics, Tokyo, Japan; LLQ, $1.0 \log I U / m L)$. HBsAg and HBV-DNA levels were measured at baseline; at weeks 4,8 and 12 during

Department of Gastroenterology and Hepatology, Juntendo University Shizuoka Hospital, Japan

Received: February 19, 2021; Accepted: March 23, 2021; Advance Publication by J-STAGE: May 14, 2021

Correspondence to Dr. Shunsuke Sato, syusato@juntendo.ac.jp 
Table. Patient Characteristics.

\begin{tabular}{|c|c|c|c|c|c|c|c|c|c|c|c|}
\hline \multirow[b]{2}{*}{ Case } & \multirow[b]{2}{*}{ Age } & \multirow[b]{2}{*}{ Sex } & \multicolumn{3}{|c|}{ HCV therapy } & \multicolumn{6}{|c|}{ HBV status before IFN-free therapy } \\
\hline & & & $\begin{array}{c}\text { HCV } \\
\text { genotype }\end{array}$ & $\begin{array}{l}\text { Liver } \\
\text { status }\end{array}$ & Regimen & Profile & $\begin{array}{l}\text { HBsAg } \\
\text { (IU/mL) }\end{array}$ & $\begin{array}{l}\text { HBV-DNA } \\
(\operatorname{logIU/mL)}\end{array}$ & HBeAg & $\begin{array}{c}\text { HBV } \\
\text { genotype }\end{array}$ & $\begin{array}{c}\text { HBV } \\
\text { treatment }\end{array}$ \\
\hline 1 & 41 & M & $2 \mathrm{~A}$ & $\begin{array}{l}\text { Chronic } \\
\text { hepatitis }\end{array}$ & SOF/RBV & $\begin{array}{l}\text { Inactive } \\
\text { career }\end{array}$ & 36.97 & 2.7 & Negative & $\mathrm{C}$ & No \\
\hline 2 & 52 & M & $2 \mathrm{~A}$ & $\begin{array}{l}\text { Chronic } \\
\text { hepatitis }\end{array}$ & SOF/RBV & $\begin{array}{l}\text { Inactive } \\
\text { career }\end{array}$ & 29.67 & 2.1 & Negative & $\mathrm{C}$ & No \\
\hline 3 & 67 & M & $2 \mathrm{~B}$ & $\begin{array}{l}\text { Chronic } \\
\text { hepatitis }\end{array}$ & $\mathrm{SOF} / \mathrm{RBV}$ & $\begin{array}{l}\text { Inactive } \\
\text { career }\end{array}$ & 84.62 & Undetectable & Negative & $\mathrm{C}$ & No \\
\hline 4 & 70 & M & $2 \mathrm{~A}$ & $\begin{array}{l}\text { Chronic } \\
\text { hepatitis }\end{array}$ & $\mathrm{SOF} / \mathrm{RBV}$ & $\begin{array}{l}\text { Inactive } \\
\text { career }\end{array}$ & 111.00 & 2.8 & Negative & B & No \\
\hline
\end{tabular}

M: male, HCV: hepatitis C virus, HBV: hepatitis B virus, IFN: interferon, SOF: sofosbuvir, RBV: ribavirin, HBsAg: hepatitis B surface antigen, HBeAg: hepatitis B e-antigen

treatment [end of treatment (EOT)]; at weeks 4, 12, and 24 after treatment; and every 24 weeks after post treatment week 24. We defined HBV reactivation as an increase in HBV-DNA $\geq 2 \operatorname{logIU} / \mathrm{mL}$ from baseline.

None of these patients had received nucleos(t)ide analogue treatment before, during, or after DAA therapy.

\section{Case 1}

The patient was a 41-year-old Japanese man co-infected with $\mathrm{HBV}$ (genotype $\mathrm{C}$ ) and $\mathrm{HCV}$ [genotype 2A; HCVribonucleic acid (RNA), $7.2 \log I \mathrm{U} / \mathrm{mL}$ ]. His pre-DAA therapy $\mathrm{HBV}$ assessment findings were as follows: $\mathrm{HBeAg}$, negative; HBsAg level, $36.97 \mathrm{IU} / \mathrm{mL}$; and HBV-DNA level, $2.7 \log \mathrm{IU} / \mathrm{mL}$. Therefore, we considered the patient an HBV inactive carrier (Table).

His HCV-RNA level rapidly decreased after starting sofosbuvir and ribavirin therapy and became undetectable in week 4. He finally achieved an SVR without adverse events. The serum HBsAg level decreased during sofosbuvir and ribavirin therapy $(-0.629 \log \mathrm{IU} / \mathrm{mL}$ at the EOT) and returned to near the baseline 4 weeks after treatment (Figure a). The HBV-DNA level also declined during treatment (maximum, $-1.5 \operatorname{logIU} / \mathrm{mL}$ in week 8) but increased again by the EOT (Figure b). After DAA therapy completion, the HBsAg level gradually decreased by $\geq 2 \log I \mathrm{U} / \mathrm{mL}$. At EOT, the patient achieved HBsAg loss 2.5 years later, and his anti-HBs became positive after 3 years (HBs seroconversion). No ALT flare was observed prior to HBs seroconversion.

\section{Case 2}

The patient was a 52-year-old Japanese man co-infected with HBV (genotype C) and HCV (genotype 2A; HCVRNA, $4.1 \log I \mathrm{U} / \mathrm{mL}$ ). His pre-DAA therapy HBV assessment findings were as follow: $\mathrm{HBeAg}$, negative; $\mathrm{HBsAg}$ level, $29.67 \mathrm{IU} / \mathrm{mL}$; and HBV-DNA level, $2.1 \operatorname{logIU} / \mathrm{mL}$. Therefore, we considered the patient an HBV inactive carrier (Table). After beginning sofosbuvir and ribavirin therapy, his HCV-RNA level rapidly decreased and became undetectable in week 4. He finally achieved an SVR without adverse events. The patient's serum HBsAg level decreased to -0.314 $\operatorname{logIU} / \mathrm{mL}$ by the EOT and returned to near the baseline 4 weeks later (Figure a). The HBV-DNA level also declined during treatment (maximum -1.0 $\log \mathrm{IU} / \mathrm{mL}$ in week 4, Figure b). After the completion of DAA therapy, the HBsAg level gradually decreased to $-0.903 \log \mathrm{IU} / \mathrm{mL}$ at posttreatment week 216. No ALT flare was observed after the initiation of DAA therapy.

\section{Case 3}

The patient was a 67-year-old Japanese man co-infected with HBV (genotype C) and HCV (genotype 2B; HCVRNA, $5.9 \log I \mathrm{U} / \mathrm{mL}$ ). His pre-DAA therapy HBV assessment findings were as follows: $\mathrm{HBeAg}$, negative; $\mathrm{HBsAg}$ level, 84.62 IU/mL; and HBV-DNA level, undetectable. Therefore, we considered the patient an HBV inactive carrier (Table). After beginning sofosbuvir and ribavirin therapy, his HCV-RNA level rapidly decreased and became undetectable in week 4. He finally achieved an SVR without adverse events. His serum HBsAg levels decreased to -0.706 $\operatorname{logIU} / \mathrm{mL}$ by the EOT and returned to near the baseline 4 weeks later (Figure a). The HBV-DNA level was undetectable before and throughout DAA therapy (Figure b). Following DAA therapy completion, the HBsAg level gradually decreased by $\geq 2 \log \mathrm{IU} / \mathrm{mL}(-2.409 \log \mathrm{IU} / \mathrm{mL}$ in post-treatment week 216). No ALT flare was observed after the initiation of DAA therapy.

\section{Case 4}

The patient was a 70-year-old Japanese man co-infected with HBV (genotype B) and HCV (genotype 2A; HCVRNA, $6.1 \log I \mathrm{U} / \mathrm{mL}$ ). His pre-DAA therapy HBV assessment findings were as follows: $\mathrm{HBeAg}$, negative; $\mathrm{HBsAg}$ level, $111.00 \mathrm{IU} / \mathrm{mL}$; and HBV-DNA level, $2.8 \log \mathrm{IU} / \mathrm{mL}$. Therefore, we considered the patient an HBV inactive carrier (Table). After beginning sofosbuvir and ribavirin therapy, his HCV-RNA level rapidly decreased and became undetectable four weeks later. He achieved an SVR without adverse events. The patient's serum HBsAg level decreased to $-0.470 \log \mathrm{IU} / \mathrm{mL}$ by the EOT and returned to near the baseline 12 weeks later (Figure a). The patient's HBV-DNA level temporarily declined from the baseline in week 2 but increased again in week 4 (Figure b). No ALT flare was ob- 


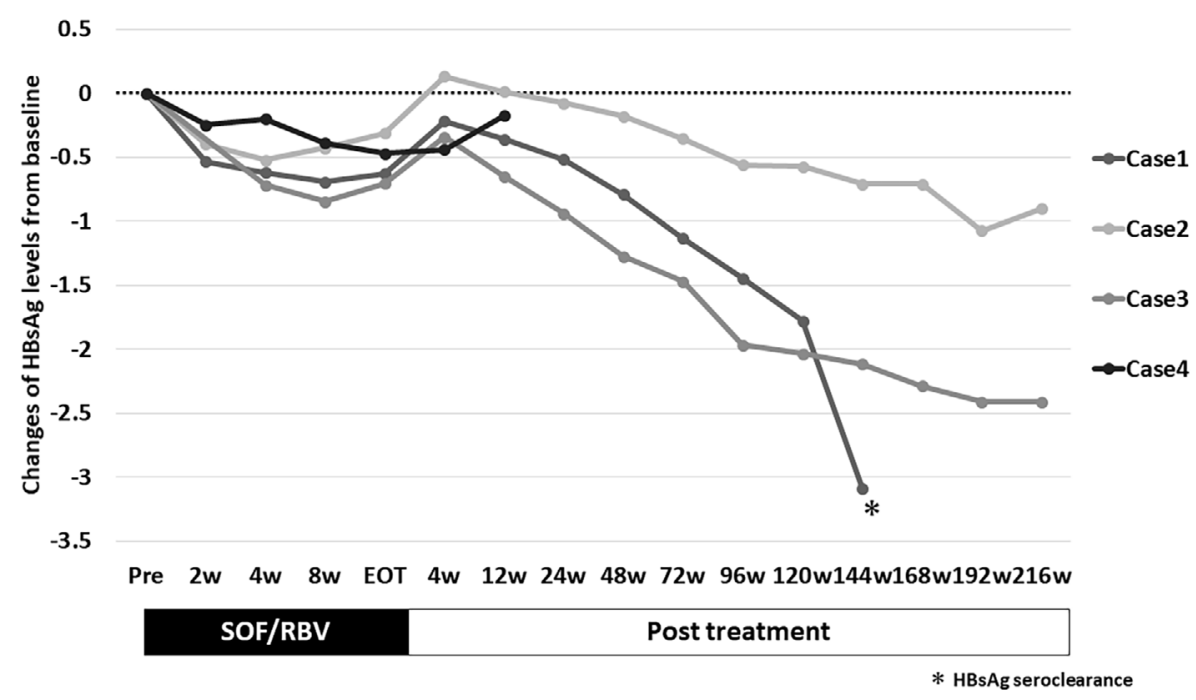

b

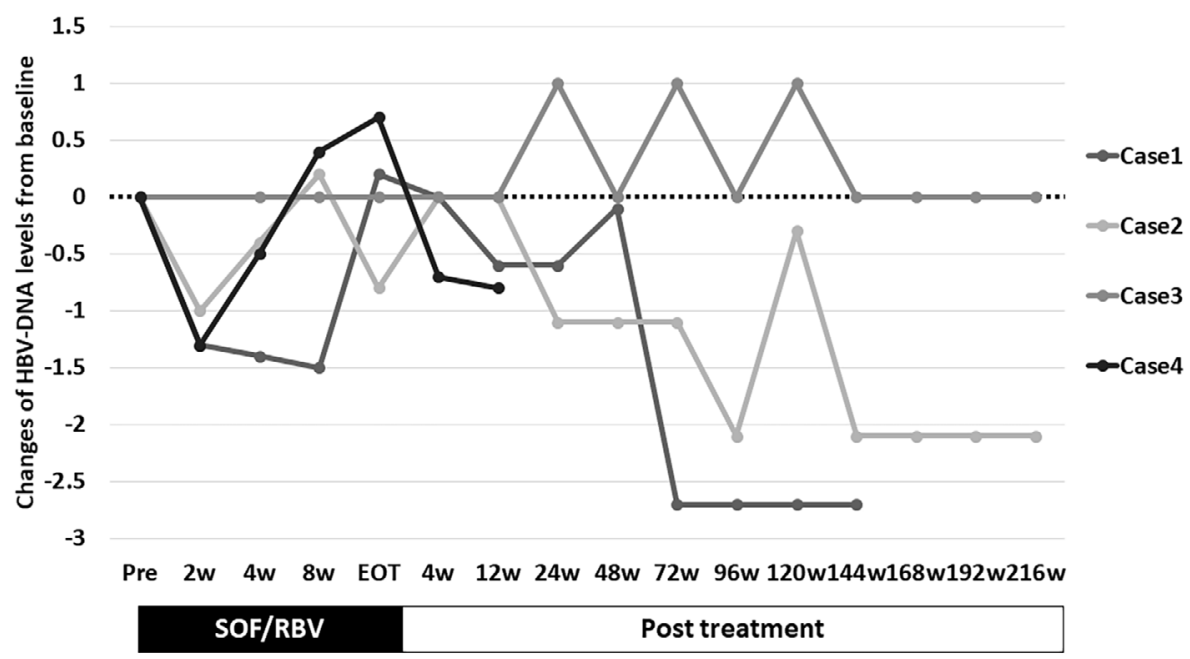

Figure. a: Serum hepatitis B surface antigen (HBsAg) kinetics in patients receiving sofosbuvir (SOF) and ribavirin (RBV) therapy for hepatitis $\mathrm{C}$ virus. The HBsAg levels had uniformly decreased (mean, $-\mathbf{- 0 . 5 3 0} \log I \mathrm{U} / \mathrm{mL}$ ) in all patients by the EOT, and then returned to near the baseline. b: Plasma hepatitis B virus deoxyribonucleic acid (HBV-DNA) kinetics in patients receiving SOF and RBV therapy for hepatitis $\mathrm{C}$ virus. The changes in HBV-DNA levels during treatment varied among patients. EOT: end of treatment, w: week

served after the initiation of DAA therapy.

\section{Discussion}

In our patients who were $\mathrm{HBV}$ inactive carriers coinfected with $\mathrm{HCV}$, the serum HBsAg levels declined during sofosbuvir and ribavirin therapy (mean $-0.530 \log I \mathrm{U} / \mathrm{mL}$ ) and returned to near the baseline after treatment. Interestingly, the impact of HBsAg decline seems greater than that observed in a previous analysis of HBsAg levels during long-term HBV therapy with tenofovir disoproxil fumarate $(-0.147 \log \mathrm{IU} / \mathrm{mL}$ in week $24,-0.208 \log \mathrm{IU} / \mathrm{mL}$ in week 48) (4). Sofosbuvir is an oral nucleotide polymerase inhibitor of $\mathrm{HCV}$-specific NS5B polymerase and acts as a chain terminator by competing with natural nucleotides, inhibiting HCV-RNA replication (5). Ribavirin is a guanosine analog that interferes with the replication of RNA and DNA viruses and is widely used in anti-HCV therapy combined with interferon or DAAs (6). However, the effect of sofosbuvir and ribavirin on HBV replication is unknown. A previous study of Taiwanese patients co-infected with HBV and HCV also showed that the HBsAg levels declined during DAA therapy and gradually increased after treatment (7). However, no specific DAA regimen showing a suppressive effect on HBsAg was identified in this study. The reason for the decline in HBsAg levels during DAA therapy is unclear. Reportedly, rapid viral clearance following DAA therapy leads to the rebalancing of the innate antiviral response in both 
the peripheral blood and liver, such as improving the natural killer cell phenotype and function (8). Based on these findings, the transient decline in HBsAg levels might be associated with the restoration of innate immunity following rapid HCV clearance by DAA therapy.

In co-infected patients, $\mathrm{HBV}$ reactivation was sometimes observed after DAA therapy-induced HCV eradication $(9,10)$; however, this did not occur in our cases for reasons we do not fully understand. A prevoius report showed that HBsAg loss occurred in $10.1 \%$ of $\mathrm{HBV} / \mathrm{HCV}$ coinfected patients treated with DAA therapy, whereas HBV reactivation (HBV-DNA $>1 \log$ increase or $>100 \mathrm{IU} / \mathrm{mL}$ if undetectable at baseline) occurred in $38.0 \%$ of patients (7). Interestingly, a sofosbuvir-containing regimen and a low HBsAg level at baseline were negatively associated with HBV reactivation in that study, results that were consistent with the present findings. Sofosbuvir and ribavirin therapy may have affected the HBV status after HCV eradication.

HBsAg loss is currently considered a functional cure and an optimal treatment endpoint in patients with chronic HBV infection (11). However, monitoring the HBsAg decline requires long-term observation, even in patients receiving nucleos(t)ide analogue treatment, which effectively suppresses the reverse transcription of HBV-DNA. Furthermore, HBsAg loss remains extremely rare (12). A previous study revealed that HBs seroconversion in patients co-infected HBV and HCV treated with DAA therapy was associated with low pre-treatment $\mathrm{HBsAg}(26.3 \%$ and $1.9 \%$ in patients with pre-treatment $\mathrm{HBsAg} \leq 10 \mathrm{IU} / \mathrm{mL}>10 \mathrm{IU} / \mathrm{mL}$, respectively) (7). In our study, 1 patient with a low baseline HBsAg level (36.97 IU/mL) showed HBs seroconversion 3 years after the EOT. The present findings suggest that sofosbuvir and ribavirin might be a novel therapeutic approach for inducing $\mathrm{HBsAg}$ suppression in $\mathrm{HBV}$ inactive carriers who are co-infected with HCV.

This study protocol was approved by the Juntendo University Shizuoka Hospital's Ethics Committee, and was performed in accordance with the 2013 revision of the Declaration of Helsinki.

The authors state that they have no Conflict of Interest (COI).

\section{References}

1. AASLD-IDSA HCV Guidance Panel. Hepatitis C guidance 2018 update: AASLD-IDSA recommendations for testing, managing, and treating hepatitis C virus infection. Clin Infect Dis 67: 14771492, 2018.

2. European Association for the Study of the Liver. EASL recommendations on treatment of hepatitis C 2018. J Hepatol 69: 461511, 2018.

3. Drafting Committee for Hepatitis Management Guidelines, the Japan Society of Hepatology. Japan Society of Hepatology guidelines for the management of hepatitis $\mathrm{C}$ virus infection: 2019 update. Hepatol Res 50: 791-816, 2020.

4. Koike K, Suyama K, Ito H, Itoh H, Sugiura W. Randomized prospective study showing the non-inferiority of tenofovir to entecavir in treatment-naïve chronic hepatitis B patients. Hepatol Res 48: 59-68, 2018.

5. Gane EJ, Stedman CA, Hyland RH, et al. Nucleotide polymerase inhibitor sofosbuvir plus ribavirin for hepatitis C. N Engl J Med 368: 34-44, 2013.

6. Hézode C, Bronowicki JP. Ideal oral combinations to eradicate HCV: the role of ribavirin. J Hepatol 64: 215-225, 2016.

7. Yeh ML, Huang CF, Huang CI, et al. Hepatitis B-related outcomes following direct-acting antiviral therapy in Taiwanese patients with chronic HBV/HCV co-infection. J Hepatol 73: 62-71, 2020.

8. Serti E, Chepa-Lotrea X, Kim YJ, et al. Successful interferon-free therapy of chronic hepatitis $\mathrm{C}$ virus infection normalizes natural killer cell function. Gastroenterology 149: 190-200.e2, 2015.

9. Chen G, Wang C, Chen J, et al. Hepatitis B reactivation in hepatitis $\mathrm{B}$ and $\mathrm{C}$ coinfected patients treated with antiviral agents: a systematic review and meta-analysis. Hepatology 66: 13-26, 2017.

10. Mücke MM, Backus LI, Mücke VT, et al. Hepatitis B virus reactivation during direct-acting antiviral therapy for hepatitis C: a systematic review and meta-analysis. Lancet Gastroenterol Hepatol 3: 172-180, 2018.

11. European Association for the Study of the Liver. EASL 2017 clinical practice guidelines on the management of hepatitis B virus infection. J Hepatol 67: 370-398, 2017.

12. Lok AS, Zoulim F, Dusheiko G, et al. Durability of hepatitis B surface antigen loss with nucleotide analogue and peginterferon therapy in patients with chronic hepatitis B. Hepatol Commun 4: 8-20, 2019.

The Internal Medicine is an Open Access journal distributed under the Creative Commons Attribution-NonCommercial-NoDerivatives 4.0 International License. To view the details of this license, please visit (https://creativecommons.org/licenses/ by-nc-nd/4.0/).

(C) 2021 The Japanese Society of Internal Medicine

Intern Med 60: 3569-3572, 2021 